\title{
異所性乳癌の経験
}

\author{
信州大学第 2 外科（主任：降䡩力男教授） \\ 小池綏男彦坂興博中藤晴羲 \\ 降粸力男
}

\section{CLINICAL EXPERIENCE OF CARCINOMA IN SUPERNUMERARY BREAST TISSUES}

Yasuo KOIKE, Okihiro HIKOSAKA, Haruyoshi NAKAFUJI and Rikio FURIHATA

Second Department of Surgery, School of Medicine, Shinsyu University

(Director : Professor Rikio FURIHATA)

1953年 1 月から1979年 9 月までの27年間に, 両側同時性乳癌 2 例を含む355例の女性乳 癌症例中に 2 例， $0.6 \%$ の異所性乳癌を経耠した。

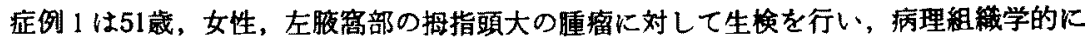
甲状腺の索状癌の転移と診断されたが，湢床的に甲状腺には異常を認めないため，开腺由

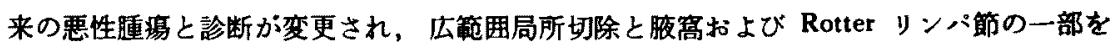
一塊として廊清した。病理組織学的に乳腺組織と癌細胞の浸潤像を認め, 乳腺組織中に固 有乳管を認めないことから迷入乳腺より発生した癌と診断した，腋窩りンパ節に転移が 1 個認められ，術後，早期に預推転移を起こした。

症例 2 は73歳, 女性, 左腋窝腫㾂が再発し, 生俟の結果, 乳癌の腋窩リンタ節転移とし て紹介された，左胶窝にはまた 3 個の腫痹が残存しており，局所切除十左乳房切断十小胸 筋切除十腋窩廊清を施行した，病理組織学的に乳房内には癌を認めず，腋简には原発性腺 管腺癌とリンパ節転移が多数認められた。腋窩には乳腺組織は認められなかったが, 異所 性乳腺より発生した乳癌と考之た。

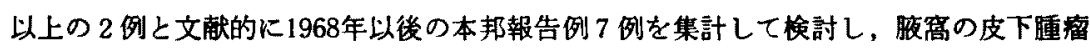
に対しては，できるだけ早く切除し，病理組織学的検索で巽所性乳癌と圽断された場合 は，広範囲局所切除十乳房切断十腋窩廊清を一塊として行い, リンバ節転移陽性の場合に は放射線照射を行う。また，異所性乳癌は血行性転移む起しやすいので，抗癌郕の投与を 強力に行らべきであることを強調した。

\section{䊰 曹}

乳腺組織は正常乳腺から離れた部位に存在することが ある。これらは総称して異所性乳腺あるいは過彩乳腺 と呼ばれており，大別して副乳腺と迷入乳腺に分けられ る”。これらの組織加癌が発生すると, 副乳癌, 迷入 乳癌と呼ばれるが，両者の篮別は困難なことが多く，ま た, 用語の使用に多少の混乱がられる。したがって, 本論文では副乳癌, 迷入乳癌を一括して異所性乳癌と し，われわれが最近経鏂した 2 例を報告するととるに， 若千の文献的考察を加えた。

\section{昰 例}

信州大学第 2 外科に打いて1953年 1 月から1979年 9 月 までの27年間に同時両側性乳癌 2 例を含む355例の女性 乳癌患者に対し手術を施行したが，異所性乳癌はそのう らの 2 例，0.6\%にすぎなかった。

应例 1. 小照○，51歳，女性

主所: 左腋窩部腫慮

家族歴：特記すべきことなし。

既往歴：4〜5歳の時, 䫟部リンバ腺結核で治療を受 けた. 46歳の時, 左単純性結節性甲状腺腫にて当科て腺 


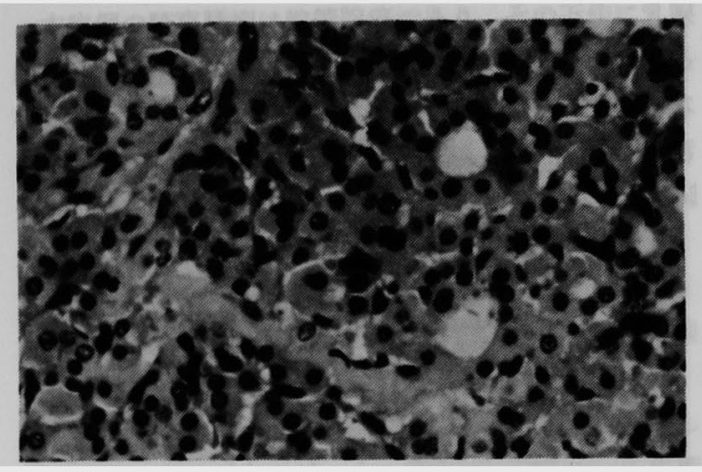

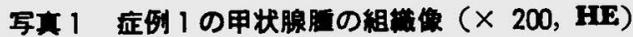
好酸性細胞腺腫

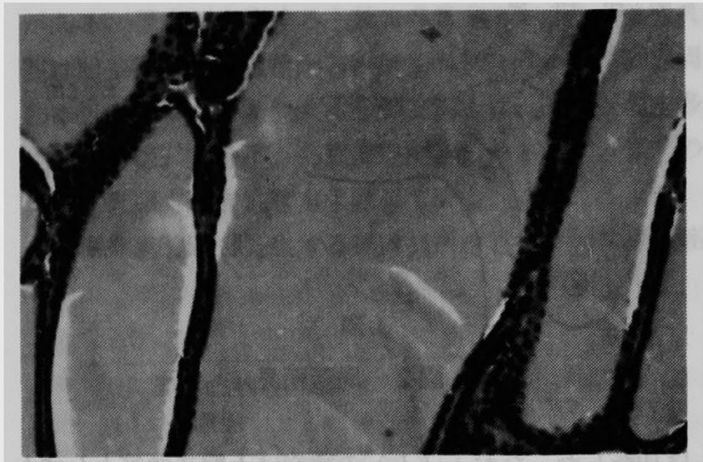

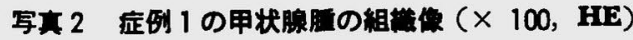
コロイド腺腫

腫の核出術を受けた。組織型は好酸性細胞腺腫（写紊 1）とコロイト腺腫（写真2）であった。

現病歴：昭和 53 年 3 月下旬, 左腋窩部に小指頭大の腫 瘤のあるのに気付いた， 5 月初旬，某外科を受診し，粉 瘤と診断された。 5 月 30 日当科を受診, 左腋窩部の小指 頭大の腫瘤に対し生検を行ら予定であったが，患者の都 合で施行しなかった８月に入り，腫瘤が增大し，皮唐 への不完全固定が出現したため，9月12日再来院した。 左腋窩部に拇指頭大で硬く，境界不鮮明で皮店への不完

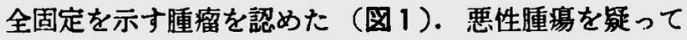
9 月18日，切除生検を施行した。病理組織学的検索では 甲状腺の索状癌の転移（写央 3) とのことであった。 甲 状腺は触診上異常を認めず, 䫋部のレントゲン検查でる 異常は認めなかった．前回の単純性結節性甲状腺腫のプ レパラート（写而1，2）を再検したが，悪性像が認め られないことから，今回の腫瘍は开腺由来の悪性腫瘍の 疑いと診断が変更され，根治手術の目的で入院した。

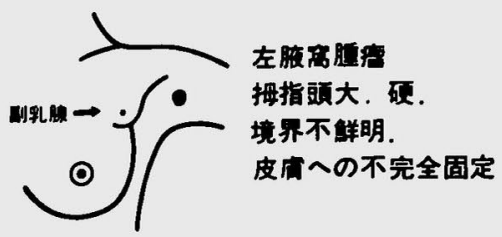

図 1 初晾時所見

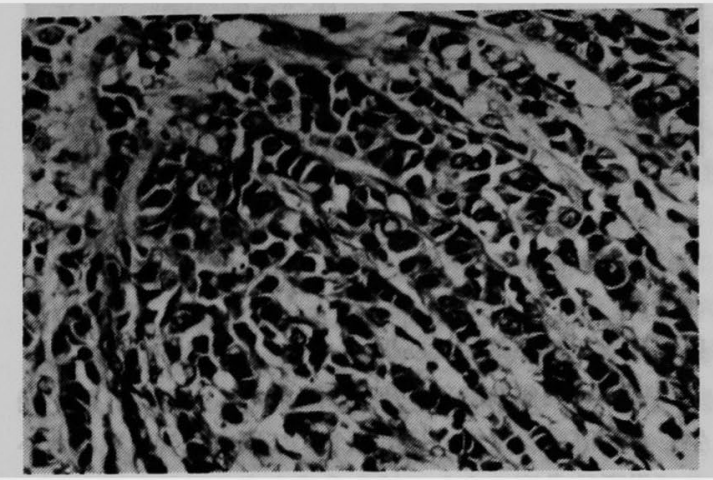

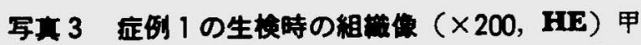
状腺の索状癌の転移と診断されたが，後に腋简の 迷入乳癌と診断か变更された。

入院時属所々見：左腋窝部に手術洀痕の硬結とその内 側に小指頭大のリンパ節らしい属瘤を触知した，両側乳 房外上方に副乳頭を認めたが，両側乳房に腫瘤は触知し なかった。

手術所見：10月 12 日，左腋窝部に $11.5 \times 5.5 \mathrm{~cm}$ の紡 錐形の皮切をおき，遗残腫瘍を含め，皮屑および皮下脂 肪を広範围に切除し，腋窩リンパ節および Rotter リン ハ節の一部を一塊として䁨清した。

病理組篗学的所見：切除された腋窝皮府の皮下に乳腺 組織の一部と癌細胞の浸潤像（写直 4）を認めたため， 生検標本の組織像（写木 3) む含めて検討し, 乳腺組織 内に固有乳管を認めないことから，迷入乳腺由来の腺癌 と診断した，腋䈪リン八節 1 個に転移が認められた。

術後経遗：左鎖骨上窝, 腋窩, 前胸壁の一部に 1 回 $300 \mathrm{rad}$ ，計5,100 rad のライナック照射を行い，同時に 5-Fluorouracil を経口的に 1 日 $600 \mathrm{mg}$, 計 $40.2 \mathrm{~g}$ 投与し て12月13日退院させた。しかし，12月31日，右側頝部 痛と右上肢のシビレ感が出現し 1 月 5 日来院した。頚部 レントゲン撮影の結果, 第Vおよび第 V暊椎に入院時認 められなかった骨破壊像を認めたため，1月17日， ${ }^{99} \mathrm{Tc}$ による骨シンチクラフィーを施行し， $\mathrm{C}_{5} \sim \mathrm{C}_{8}, \mathrm{Th}_{10}, \mathrm{~L}_{1}$, L、およひ第10肋骨先端に異常集積像を認めたので，放 


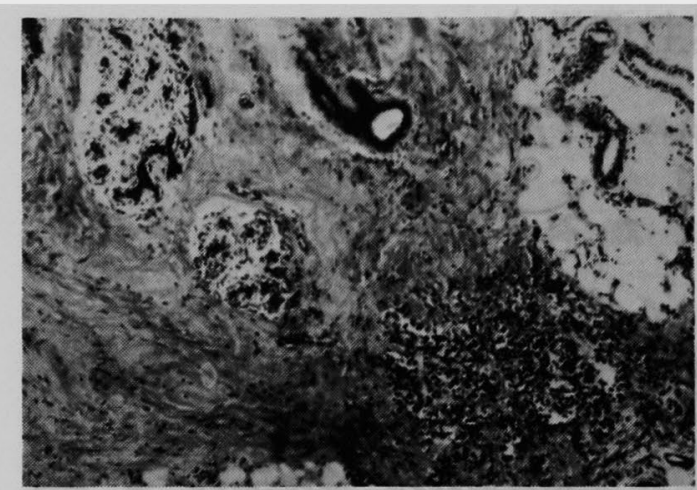

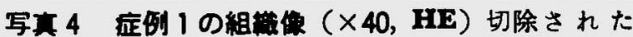
腋窝皮店の皮下に，乳腺組樴の一部と癌細胞の浸 潤像を認める。

射線照射，抗癌斧および男性ホルモンの投与を行った。 本症例は両側前胸部に副乳頭を認めているが, 癌が発 生した腋窝乳腺組織には乳頭および固有乳管を認めない ので異所性乳癌のうちの迷入乳癌と考えられる.

症例 2 , 望 $\bigcirc$ 美 $\bigcirc, 73$ 歳, 女性

主訴 : 左腋窩腫瘤

家族歴：父親が60歳で胃癌で死亡．姉が80歳で右乳癌 （浸潤性乳頭腺管癌）にて当科で手術を受けた。

既往歴：17〜18歳の時，腎炎に罹患. また，20年来， 本態性高血王にて治療を受けている，42歳で閉経.

現病歴：昭和51年, 左腋窩腫瘤に気付き，某病院で 腫瘤の摘出を受けた。病理組織検査は行われず，“脂肪 のかたまり”であったよいわれた．3年後の昭和54年 4 月，再び左腋窩腫瘤が出現したため，上記病院で生検 を受け，乳癌の腋窩リンパ節転移として当科に紹介され た.

入院時局所所見 : 両側乳房に腫瘤および硬結は認めな い. 左腋墖に $4.1 \times 3.2 \mathrm{~cm}$ で硬く，可動性の少ない皮屑

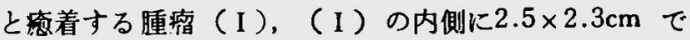
硬く，可動性で病着のない腫瘤（II），（II）の内側に

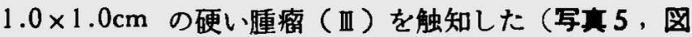
2). ${ }^{99} \mathrm{Tc}$ シンチクララフィーでは骨の異常集積像は認め なかった。

手街所見：6月11日,左腋窝から乳房にかけて紡錐形 を2つつなき合せたような細長い皮切をおき，広範囲皮 下脂肪切除と Patey の手術 ${ }^{2} に$ 準じて，大胸筇を保存 し，小胸筋を切除して乳房切断と腋窩の搱清を行った。 リンパ節廊清に際して長胸神経は温存したが，胸背神程

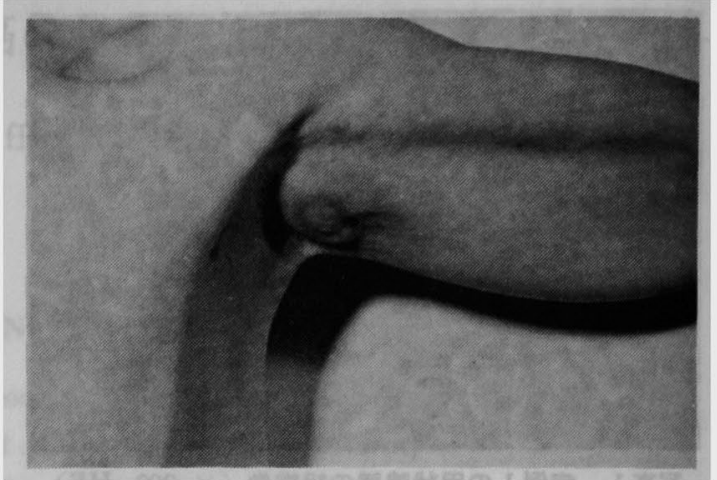

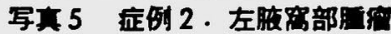

局 所所見

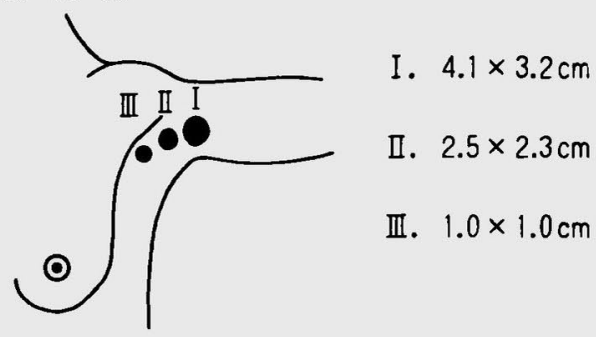

図2局所所見

は切断した.なお，（Ｉ）の腫瘤は上腕三頭筋とわずか に席着していた

病理組織学的所見：乳房内乳腺には癌を認めず, 腫 瘤（I） は原発性の腺管腺癌で（写正 6), 腫瘤 (II), （III）はリンパ節転移でその他に多数のリンパ節転移が 認められた。詳細な㭘索を行ったが乳腺組織は見出せな かった。

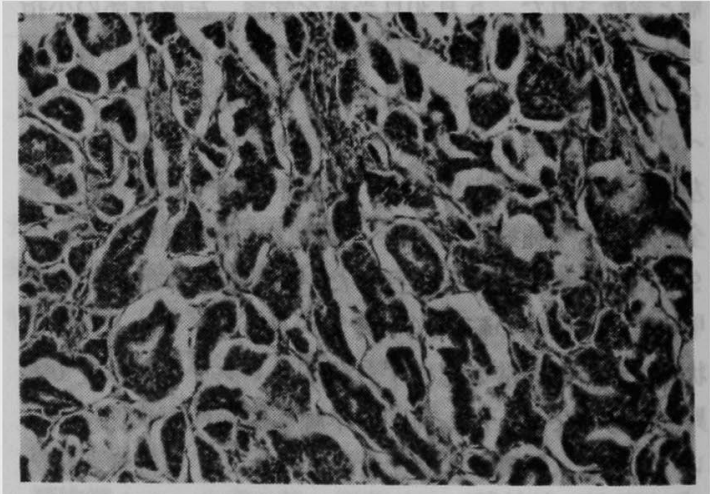

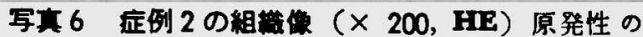
腺管腺癌 
本症例の渡窝尰瘤は腺管腺癌であり，その近傍に乳腺 組箖は見出せなかったが，瘦の組維像が乳症類似である ことから，異所性乳癌と考える。迷入乳癌か副乳癌かは 敗窝に副乳頭を認めないので，迷入乳癌ではないかと考 えられるが，3年前他医にて生検が行われているため副 拜頭の存在に関しては明らかではな。

\section{考按}

異所性乳腺あるいは過剩孚腺と呼ばれるるのは副乳腺 と迷入乳腺に分けられる. 副睬腺は腋窩から外生殖器, 大騩内面に至るいわゆる乳腺堤線, milk line に一致し て存在するむのが多いが, その他, 頓, 䫓, 局, 胸腹部

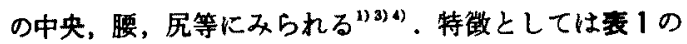
よ5に乳頭と固有乳管を有方るものと, 乳頭のみのもの がある．後者が多発すると特に多乳頭とい5 ${ }^{3)}$. 迷入乳 腺は胎生期に正常乳腺から分離された組織が正常乳腺周 国に迷入したため発生するむのと解され，腋䆚が最む多

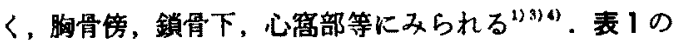
ように乳頭む固有乳管む久除している。

異所性乳腺が発生する癌は異所性乳癌の他に副乳癌

表 1
翼所性 (過剩) 乳腺
I. 副乳腺
乳頭 $(+)$ ，固有乳管 $(+)$
乳頭 $(+)$ ，固有乳管 $(-) \cdots$ 多乳顽
II. 迷入解腺
秏頭 (一), 固有乳管 (一)

あるいは迷入乳癌と呼ばれているが，用語の使用に多少 の湦乱がみられる．異所性乳瘦の本邦報告例のらち1968 年以前の症例12例瑔雄ら゙によって集計されているの で，われわれはそれ以後の報告例を9 例集計した（表 2). われわれの集計例 9 例中 6 例は異所性乳癌といら 用語を用い，3 例は副乳癌あるいは副乳腺腫湯とい5用 語を用いて報告されているが，報告内容を表 1 の分類に 従って分類してみると, 異所性乳癌 6 例中では副乳癌お よび迷入乳癌がそれぞれ 3 例ずつであった．副乳癌 3 例 中1 例は副乳癌であったが，他の 2 例は記載がなく判定 できなかった，われわれの集計例では副乳癌 4 例，迷入 乳癌 3 例であり，泉雄ら5)の集計例では副乳癌 8 例，迷 入乳癌 4 例であるので，本邦報告例では副乳癌が多い。 しかし, 臨床病理学的に副乳癌と迷入乳癌を区別するこ とが難かしい場合がある上，特殊な症例 ${ }^{13)}$ を除き，副乳 癌子迷入乳癌と同様に，正常乳腺近傍に発生することが 多く，また，前述のよ5に用韭の使用るまちまちである ので，本論文では副乳癌と迷入乳癌をあえて区別しない で異所性乳癌として一括して検討する。

巽所性乳癌の頻度はそれほど多いものではなく，われ われの355例の女性乳㾔中では 2 例，0.6\%であり，富 山ら

また，Chiari” は918例中 3 例，0.3\%かi迷入乳㾔（Das Karzinoma in aberrantem Brustdrüsengewebe) であった と報告している。

表 2 に示すように，われわれの集計例 9 例（以下集計

表 2 異所性乳量の啹告例

\begin{tabular}{|c|c|c|c|c|c|c|c|c|c|c|}
\hline 㥨告名 & 叝告者 & 年度 & 性 & 年齢 & 部位 & 大きさ & 㯴断法 & 術 式 & 組織猃断 & $\begin{array}{c}\text { 診 } \\
\text { (発生紫地) }\end{array}$ \\
\hline 翼所生乳境 & 富 $山^{6]}$ & 1968 & 우 & 41 & $\begin{array}{l}\text { 不明 } \\
\text { 籍骷 }\end{array}$ & 小豆大 & 生镇 & $\begin{array}{l}\text { 乳房切断術 } \\
\text { 做部清 }\end{array}$ & 硬 & $\begin{array}{c}\text { 迷入乳缯 } \\
(?)^{2}\end{array}$ \\
\hline 副乳腺腫寒 & 安河内” & 1968 & 운 & 60 & $\begin{array}{l}\text { 不明 } \\
\text { 腋蓠 }\end{array}$ & 不 明 & 生検 & 腫要摘出 & 明 & 不 \\
\hline 副 秏 瘦 & 金 沢 $^{8}$ & 1970 & 우 & 61 & 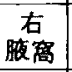 & 示指頍大 & 生検 & $\begin{array}{l}\text { Grunert } \\
\text { Auchincloss }\end{array}$ & 硬 & 副 乳 瘦 \\
\hline 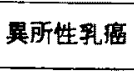 & 平 出 $^{9}$ & 1971 & ㅇ & 43 & $\begin{array}{c}\text { 左 } \\
\text { 腋窝 } \\
\end{array}$ & 大豆大 & 生検 & $\begin{array}{l}\text { 乳房切断術 } \\
\text { 渡彰清 }\end{array}$ & 乳頭腺管癌 & 副乳痛 \\
\hline 筫所性乳据 & 有 $2^{101}$ & 1973 & 우 & 64 & $\begin{array}{c}\text { 右 } \\
\text { 腋简 }\end{array}$ & $5.7 \times 5.0 \mathrm{~cm}$ & マンモグラフィー & 定型的根治手術 & 䯣様腺管癌 & 副 乳 痹 \\
\hline 異所性乳瘦 & 大 侬 ${ }^{111}$ & 1974 & 우 & 63 & 崖 & 拇指顽大 & 生検 & 根治的乳房切断術 & 明 & 副乳痛 \\
\hline 副乳密 & 小 林 ${ }^{121}$ & 1976 & q & 43 & 右 & 明 & 不明 & 不明 & 涟様腺管痹 & 不 明 \\
\hline 異所性乳癌 & 著 者 & 1979 & 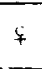 & 51 & 左 & 拇指頍大 & 生検 & $\begin{array}{l}\text { 局所切除 } \\
\text { 䔃盛郭清 }\end{array}$ & 腺管腺癌 & 迷入乳瘦 \\
\hline 異所性拜畠 & 著 者 & 1979 & $q$ & 73 & 左 & $4.1 \times 3.2 \mathrm{~cm}$ & 生検 & $\begin{array}{l}\text { 乳房切断術 } \\
\text { 腋敦清 }\end{array}$ & 腺管腺蹈 & $\begin{array}{c}\text { 迷入蝺癌 } \\
(?)\end{array}$ \\
\hline
\end{tabular}


例と略す)について臨床的に娭討する。年龄は最年少 41 歳，最年長73藏，平均年螘55.4藏で，60歳代が 4 例と最

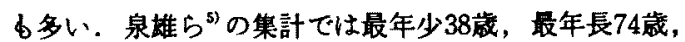
平均年龄53.6歳で，40歳代か 5 例と最む多く，ついで60 歳代 3 例であった。Ｃ（ｉari ${ }^{14) ~}$ は最年少28歳，最年長80 藏，平均年踰52歳で50歳が560歳代に多いと報告してい

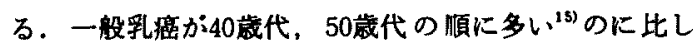
て，やや高年龄㸴に㑯いている.

腫瘤の発生側は集計例中の記載例 7 例中 4 例が左側, 3 例が右㑡で左側に多く，泉雄ら ${ }^{5)}$, Chiari ${ }^{14)}$ む左側 が多いと報告している。しかし，Smith ら"の迷入乳癌 (carcinoma of aberrant breast tissue) 3 例の報告例は全 例右側であった。 また，発生部位としては集計例全例括 よび Smith ら“の3例は腋简であるが，泉雄ら”の集計 では 8 例が腋窝， 2 例が大胸筋下で，乳房下扰よび旁胸 骨がそれぞれ1例であった。また，Chiari'10 は60例中， 腋窝43例，鎖骨下窝 6 例，胸骨傍 6 例，剣状突起部 5 例 と報告しており，腋窝が最も多いが他の部にもみられ る。しかし，以後は腋窩に発生したものについてのみ㛟 討する。

腫瘤の大きさは大豆大から鷄卵大くらいまでで，表面 は平滑から不整である。一般に大きいリンハ節あるいは 汗腺腫㻛に似ているので，他の疾患と誤診されやすい。 Kanazawa $5^{81}$ は鑑別診断として，(1) 他の部からの転 移，司) 脂腺あるいは汗腺の病变，(3) 脂肪腫，(4) 結 核を含むリンハ晸医患等を上げている．われわれの症例 1 は初猃時粉瘦と謓診されている。

異所性乳癌の診断は，一般に難かしいことが多く，集 計例では 9 例中 7 例が生検によって診断が下され，1 例 のみがマンモクラフィーにより診断されている，われわ れの症例 1 は生検診断によっても正診が下されず，甲状 腺癌の転移あるい、汗腺由来の悪性腫瑒と誤診されてい る.

䠦床症状としては，腫瘤の触知のみが最も多いが， Chiari' ${ }^{14)}$ は進行すると上肢に放散するリウマチ様疼痛が 出現すると述へ，大塚ら ${ }^{11}$ の症例は腹简腫瘤より血性の 分泌物をみたと云い，Kanazawa ら 压迫すると乳计が出たと述べている。

手術々式としては，われわれの1例は広籍囲局所切除 と腋窩漂清を行い，他の 1 例は局所切除十大胸筋保存小 胸筋切除の乳房切断術十腋䆚廓清を行った。集計例では 局所切除に加之るに乳房切断+腋窝廊清 $(\mathbf{B r}+\mathbf{A x})$ あ るいは定型的根治手術 $(B r+A x+M j+M n)$ が多い。
Kanazawa $5^{83}$ は Grunert 法に基づく腋窝腫场切除と Auchincloss 法による䐉简リンパ節邡清と乳頭保存主乳 腺切除を行っている. Smith ら“は 3 例中 1 例化局所切 除を行い，2 例は局所切除と腋䆚筙清を行っている。し たがって，腋窩の異所性乳癌に対しては，局所の十分な 切除に加えるに乳房切断と腋简倣清は必須と考えられ， 胸筇の切断は癌の進行状態によって考虑すべきものと考 える.

補助療法としてては放射線照射を勃める人が多くChi-

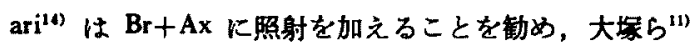
は $B_{\mathbf{r}}+\mathbf{A x}+\mathbf{M j}+\mathbf{M n}$ に照射を加えることを锄めてい る. Smith ら“は全例に腋窝と鎖骨上窩に照射を行って いるが，5ち1例は局所切除十放射線照射の治療で忧後 13年後にむ再発なく生存していると報告している.われ

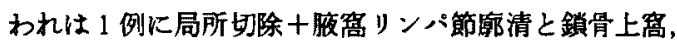
腋富，前胸壁の一部に放射線照射を行った。補助療法と しては，廊清リンハ節に転移が認められた場合には，鎖 骨上骷および腋窩への放射線照射が必要であるが，轻移 が喼められない場合には照射の必要はないと考えられ， せしろ強力な抗癌用の投与が必要であろら。

異所性乳癌の組織像は，われわれの 2 例佉䯣様腺管癌 に近い腺管腺癌であったが，集計例，Chiari'1") の集計例 をみても，一般乳癌の組織像と变るところはない。

腋筒に発生する異所性乳癌はリンバ節が腫瘁の近くに 存在するので、リンバ節転移を起こしやすいと考えら れ，また，腋窝血管子近いので，われわれの症例 1 が行 後放射線照射，抗癌剤の投与にあかかからず，早期に頝 椎転移を起こしているよらに，血行性転移す起こしやす いのではないかと考之られ，予後は一般乳癌より惠いの ではないかと推測される。大塚ら"1) 。異所性乳癌は腋窝 リンパ節に転移しやすく，周曲への浸潤が早期におこ るため，予後不良であると述へている。しかし，Smith ら”の症例の上5に手術の13年後に再発なく生存してい る症例もある。

われわれ外科医は Smith らする述へているように乳房 の末端部とくに腋窝の皮下に腫挹を認め大場合には，異 所性乳癌を念頭におく必要があり，放置することなく， できるだけ早く切除して病理組藏学的検索を行らべきで ある。

\section{耛論}

信州大学第 2 外科において1953年 1 月から1979年 9 月 までの27年間に同時両側性乳癌 2 例を含む355例の女性 乳癌症例中 2 例， $0.6 \%$ 異所性乳癌（迷入乳癌）を諗 
め, 文献的に考察した結果以下の結論を得た。

1）腋窝皮下腫瘤の中には異所性乳瘦のあることを念 頭におくべきである。

2）腋窩の皮下に原因不明の腫㢞を認めた場合には， できるたけ速かに切除を行い，病理組織学的検索を行う べきである。

3）腋䆟の異所性乳癌はリンパ節転移および血行性転 移を起こしやすい.

4）治潦としてては，去範囲局所切除十乳房切断十腋窩 麻清を行らべきである。

5）補助療法としては放射線照射と抗癌剛の投与が推 捊される。

（本論文の要旨は第 41 回日本臨床外科医学会総会にお いて発表した。

稿を終えるにあたり，御教授いたたいた信州大学中检 病理部丸山雄造先生に深謝いたします。）

\section{文献}

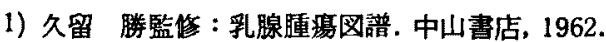

2) Patey, D.H. and Dyson, W.H.: The prognosis of carcinoma of the breast in relation to the type of operation performed. Brit. J. Cancer, 2: 7-13, 1948.

3) 武藤完雄, 桂 重次監㜪 金原出版， 1968.

4) Smith, G.M.R. and Greening, W.P.: Carcinoma of aberrant breast tissue. Brit. J. Surg., 59: 89-90, 1972.

5）泉雄 勝, 曰井 龍, 高野晃寧他 : 異所性乳腺
尰癔の 3 侧，癌の臨床，14:884-888, 1968.

6) 富山次郎, 安達秀治, 土地邦和他: 異所性程缹 の2 例，日癌治会誌，3:199,1968.

7) 安河内浩 : 腋穸部副乳腺腫場，日癌治会誌，3: $199,1968$.

8) Kanazawa, K., Ishikawa, K., Kusama, S., et al. : Carcinoma of the axillary accessory mammary gland, 東京医学, 78: 99-103, 1970.

9) 平出兼雄, 赤井貞应, 島田寬治他 : 異所性乳癌 の1例について, 日外会誌, $72: 711,1971$.

10）有沢永二，種子田 変，大西峰雄他 : 異所性 乳癌と思われる1症例，日外会誌，74：704， 1973.

11）大塚芳和，加藤哲男，高椋正俊：翼所性乳瘦の 1 例，日臨外会誌，35：78，1974.

12）小林俊三，片岡誠, 永井良治他: 副孚癌の 1 例，日外会誌， $77: 1608,1976$.

13) Guerry, R.L. and Thomas, H.R.P.: Carcinoma of supernumerary breast of vulva with bilateral mammary cancer. Cancer, 38: 2570-2574, 1976.

14) Chiari, H.H.: Zur Frage des Karzinoms in aberrantem Brustdrüsengewebe. Beitr. klin. chir., 197: 307-314, 1958.

15）小池綏男, 久米田茂意, 若林正夫他: 乳腺のリ ソパ球浸潤珄随様瘦の臨床的検討, 信州医誌, $27: 169-174,1979$. 